\title{
Potentiality of using Cissus Populnea Stem Fibre as Reinforcement for Cement Fibre Board Produced from Waste Paper
}

\author{
Akinbosoye T. B. S and Olaoye K. O. \\ Wood and Paper Technology Department, \\ Federal college of Forestry, Jericho Ibadan. Oyo State. \\ Nigeria
}

\begin{abstract}
This research work studied the utilization of a renewable, non-hazardous fibre processed from cissus populnea plant and pulp fibre obtained from recycled waste paper for production of low cost, medium density boards suitable for ceiling and walling applications.

Cissus fibres were mixed at four different percentage level of $0,2,4,6$ and $8 \%$ by weight of cement with a constant mass of pulp fiber and cement to form a total matrix composition of cissus fibre, pulp fibre and cement. The mixture was compressed in a square mold of dimension $150 \mathrm{~mm} \times 150 \mathrm{~mm} \times 20 \mathrm{~mm}$ at a pressure of 5 bar to produce a medium density boards of volume $(150 \times 150 \times 10) \mathrm{mm}^{3}$. A total boards of 36 samples were produced and subjected to impact energy, water absorption, thickness swelling, density and thermal conductivity tests.

The impact energy of the board range between 3.08 and 3.98J, water absorption of 0.24 and $0.30 \%$, Thickness swelling of 0.52 and $0.90 \%$, Density of $670 \mathrm{~kg} / \mathrm{m}^{3}$ to $735 \mathrm{~kg} / \mathrm{m}^{3}$ and Thermal conductivity of $0.075 \mathrm{~W} / \mathrm{m} . \mathrm{K}$ and $0.092 \mathrm{~W} / \mathrm{m} . \mathrm{K}$. The results of the properties tested showed a moderate relative standard values as compared to commercial fiber ceiling boards. The use of cissus fibre will eliminate energy consumption involved in the processing of synthetic fibres and also reduce the present and future environmental hazard that synthetic fibre based composites could cause to human health.
\end{abstract}

Keywords: Cissus Fibre. Synthetic Fibre. Sorption Properties. Impact Energy. Thermal Conductivity.

\section{INTRODUCTION}

In recent research developments about the importance of synthetic and natural lignocelluloses fibres as a versatile material for reinforcement in the production of fibre reinforced composites (FRC). Plain non-reinforced cementitious materials suffered low tensile strength, they are brittle and require reinforcement before they can be used as construction materials when subjected to tensile loading. Meanwhile scholars have revealed that there is high energy consumption and environmental health hazards constituted when synthetic fibres such as asbestos, Polyethylene, glass, carbon fibre etc. are processed for their utilization as reinforcement materials in the production of fibre reinforced composites (FRC) that are widely used for building construction. Even some of the manufactured end products from synthetic fibre has been proved to constitute health hazard when in service, example is asbestosis caused by inhaling asbestos ceiling board particles.

As a result of this challenge, attention has now been shifted to utilization of renewable natural lignocelluloses biofibres, These fibres are renewable, non-hazardous, environmental friendly and easy to handle during processing, they have inherent physical and mechanical properties such as toughness, high strength to weight ratio and high tensile strength that make them useful in the production of fibre reinforced composites which could also alleviate the problems of high price among contemporary building materials such as corrugated aluminum, asbestos cement board and galvanized roofing sheets.

Fibre control multiple cracking and reduce deformation at all stress level thus imparting post - yield and post-cracking behaviour, Fracture toughness, ductility, thus energy absorption capacity of the composite are then substantially improved (Oladele et al, 2009). Sisal, bagasse, banana fibres have been experimented by some authors as reinforcement materials in the manufacturing of FRC and the results of their findings on the various properties tested fall in line with the engineering standard parameters that are usually considered before FRC can be recommended for some specific applications. This development has also assisted in production of low cost building materials using natural fibres and recyclable wood based waste fibrous materials such as waste paper.

Waste paper are generated daily in tons, it can be recycled and converted into another useful products, otherwise use as a secondary fibre which can also serve as a filler material in FRC production. More frequent use of waste paper in FRC production may likely prevent the present and future menace that the enormous waste paper generated could have caused. Therefore, this research work focused on utilizing pulp fibre from waste paper and natural lignocelluloses Cissus populnea plant fibre for the production of medium density fibre reinforced - cement board hence, exploring its suitability for ceiling or side walling applications.

Cissus populnea is a high fibrous plant (Table 1.0) having unique characteristic of high crude gum composition of $38.3 \pm 1.9-40.4 \pm 3.5 \mathrm{~g} / 100 \mathrm{~g}$ on dry basis (Owuno et al, 2012). It is widely known for its mucilage (gum) consumption and numerous medicinal values but no record of its utilization as fibrous material. 
Table 1.0 Proximate Analysis of Cissus populnea

\begin{tabular}{lc}
\hline Parameters & Amount in percentage (\%) \\
\hline Moisture & 20.10 \\
Ash & 12.59 \\
Insoluble Ash & 00.10 \\
Fat & 12.31 \\
Crude Fibre & 60.71 \\
Protein & 04.35 \\
\hline
\end{tabular}

Source: Alakali et al. (2009)

\subsection{Sample Collection and Preparation}

\subsection{MATERIALS AND METHODS}

Locally sourced fresh cissus populnea stems of about $10 \mathrm{~cm}$ long and $90 \%$ moisture content were manually de-pithed and oven dried to a constant mass. The fibres were removed and cut into length of $20-30 \mathrm{~mm}$ suitable for reinforcement. A bag of Portland cement (elephant brand) procured for the production of the boards was stored in a tight sealed container to avoid moisture absorption before use and the waste papers that were recycled into pulp were obtained from spent office papers in Federal College Forestry Ibadan, Oyo state Nigeria. The papers were soaked in water for three days, digested by using a disintegrator and finally drained before oven drying to a constant mass.

The matrix for the production of the boards was shown in Table 2.0. Each proportion was mixed to form a slurry before pouring into wooden mold of $150 \mathrm{mmx} 150 \mathrm{~mm} \times 20 \mathrm{~mm}$ placed on polythene nylon. The surface of the mold was also covered with polythene nylon before the cold pressing to enhance the surface smoothness of the board surface. Thereafter, the mold was vibrated using motorized vibrator to allow uniform distribution of the slurry across the entire surface area of the mold.. Hydraulic cold press machine rated 25bar maximum pressure was used to compress the boards. Proposed sample thickness of $10 \mathrm{~mm}$ was obtained at a pressing pressure of 5bar and this pressure was constantly maintained and left for $24 \mathrm{hrs}$ before de molding. All samples were cured in water for $12 \mathrm{hrs}$ and air dried for $24 \mathrm{hrs}$ under room temperature of $21-27^{\circ} \mathrm{C}$ before they were subjected to impact energy, water absorption, thickness swelling, thermal conductivity and density tests.

Table 2.0 Cissus fibre, Pulp fibre and Cement Mixing Proportion for Board Production

\begin{tabular}{|c|c|c|c|}
\hline $\begin{array}{c}\text { \% Fibre by weight } \\
\text { of cement }(\mathrm{g})\end{array}$ & Dry pulp fibre (g) & Cement (g) & Total weight of matrix (g) \\
\hline 0 & 5 & 100 & 105 \\
\hline 2 & 5 & 100 & 107 \\
\hline 4 & 5 & 100 & 109 \\
\hline 6 & 5 & 100 & 113 \\
\hline
\end{tabular}

\subsection{Physical properties Test}

The samples were prepared in accordance with Standards for testing materials (ASTM D743-13, 2013.) The final size of each test sample was $150 \mathrm{~mm}$ X $100 \mathrm{~mm}$ X $10 \mathrm{~mm}$ and 36 samples were tested for the selected properties.

\subsubsection{Water Absorption and Thickness swelling (immersion method)}

Initial weight of test samples at room temperature of $25^{\circ} \mathrm{C}-27^{\circ} \mathrm{C}$ were determined prior to horizontal submerged of the samples in water. The samples were removed from water after $24 \mathrm{hrs}$ and allow to drain before final weights were taken. The water absorption and thickness swelling of the samples were computed using equation 4 and 5

$\%$ Water Absorption $(W A)=\underline{W 2-W 1} \times \underline{100} \ldots \ldots . . .(4)$

W1 1

$W 1(\mathrm{~g})=$ Initial weight before soaking

W2 $(\mathrm{g})=$ Final weight after $24 \mathrm{hrs}$.

$\%$ Thickness Swelling $(W T)=\frac{T 2-T 1}{T 1} \times 100 \ldots \ldots . .(5)$

$\mathrm{T}_{1}(\mathrm{~mm})=$ is the thickness of the sample before immersion

$\mathrm{T}_{2}(\mathrm{~mm})=$ is the thickness of the sample after immersion 


\subsubsection{Density}

The mass of each sample was determined using sensitive weighing scale of $5 \mathrm{~kg}$ maximum weighing capacity and the densities of the samples were determined using equation 6

Density $=m / v$ $-6$

$\mathrm{m}=$ mass of the sample $(\mathrm{kg})$

$\mathrm{v}=$ volume of sample $\left(\mathrm{m}^{3}\right)$

\subsection{Impact Energy Test (Free Fall Method)}

A sample was suspended on two ends support of span $100 \mathrm{~m}$ placed at the base of calibrated impact energy testing equipment and a steel ball of known mass was allowed to drop freely on the sample from a recorded least vertical height, the initial height from where the ball falls was gradually increased until failure (cracking) of the sample occurred. The final height at which failure occurred was recorded and the impact energy was computed in joule (J) using equation 3

$\mathrm{E}=\mathrm{mgh}$ .3

$\mathrm{m}=$ mass of steel ball $(\mathrm{kg})$

$\mathrm{g}=$ acceleration due to gravity $\mathrm{m} / \mathrm{s}^{2}$

$\mathrm{h}=$ height of the fall at which sample failure occurred $(\mathrm{m})$

$\mathrm{E}=$ Impact energy $(\mathrm{J})$

\subsection{Thermal conductivity test (Non- steady state method)}

Thermal conductivity test was carried out using digital KD2 pro-thermal properties analyzer, (KD2 pro utility). The probe of the equipment was directly inserted into each sample and the value of the thermal conductivity displayed on the KD2 meter screen was recorded for evaluation.

\subsection{Statistical Analysis}

Data obtained were subjected to descriptive statistics, analysis of variance (ANOVA) and line graph.

\subsection{Results}

\subsection{RESULTS AND DISCUSSION}

Table 3.0: Computed mean values of the properties of Cissus populnea stem fibre and pulp fibre reinforced-cement boards

\begin{tabular}{|c|c|c|c|c|c|c|c|c|}
\hline $\begin{array}{c}\text { Mass of } \\
\text { fibre (g) }\end{array}$ & $\begin{array}{c}\text { Mass of } \\
\text { dry pulp } \\
\text { fibre } \\
\mathbf{( g )}\end{array}$ & $\begin{array}{c}\text { Mass of } \\
\text { cement }(\mathbf{g})\end{array}$ & $\begin{array}{c}\text { Total weight of } \\
\text { Composite } \\
\text { matrix }(\mathbf{g})\end{array}$ & $\begin{array}{c}\text { Impact } \\
\text { Energy(J) }\end{array}$ & $\begin{array}{c}\text { Water } \\
\text { Absorption } \\
(\boldsymbol{\%})\end{array}$ & $\begin{array}{c}\text { Thickness } \\
\text { Swelling (\%) }\end{array}$ & $\begin{array}{c}\text { Density } \\
\left(\mathbf{k g} / \mathbf{m}^{\mathbf{3}}\right)\end{array}$ & $\begin{array}{c}\text { Thermal } \\
\text { Conductivity } \\
(\mathbf{W} / \mathbf{m} . \mathbf{K} .)\end{array}$ \\
\hline 0 & 5 & $\mathbf{1 0 0}$ & $\mathbf{1 0 5}$ & 3.08 & 0.24 & 0.52 & 670 & 0.085 \\
\hline 2 & 5 & $\mathbf{1 0 0}$ & $\mathbf{1 0 7}$ & 3.14 & 0.26 & 0.53 & 690 & 0.087 \\
\hline 4 & 5 & $\mathbf{1 0 0}$ & $\mathbf{1 0 9}$ & 3.61 & 0.27 & 0.57 & 710 & 0.092 \\
\hline 6 & 5 & $\mathbf{1 0 0}$ & $\mathbf{1 1 1}$ & 3.98 & 0.27 & 0.83 & 720 & 0.088 \\
\hline 8 & 5 & $\mathbf{1 0 0}$ & $\mathbf{1 1 3}$ & 3.64 & 0.30 & 0.90 & 735 & 0.075 \\
\hline
\end{tabular}

Table 4. Engineering and material science standards for ceiling boards

\begin{tabular}{|c|c|c|c|c|c|c|}
\hline $\begin{array}{c}\text { Density } \\
\left(\mathbf{K G} / \mathbf{M}^{\mathbf{3}}\right)\end{array}$ & $\begin{array}{c}\text { Compression } \\
\text { strength } \\
\text { (KPA) }\end{array}$ & $\begin{array}{c}\text { Impact } \\
\text { strength } \\
(\mathbf{J})\end{array}$ & $\begin{array}{c}\text { Hardness } \\
\times \mathbf{1 0}^{\mathbf{3}}\end{array}$ & $\begin{array}{c}\text { Water } \\
\text { absorption, } \\
\text { WA (\%) }\end{array}$ & $\begin{array}{c}\text { Thermal } \\
\text { conductivity } \\
\text { (W/M.K) }\end{array}$ & $\begin{array}{c}\text { Thermal } \\
\text { resistivity } \\
\text { (M.K/W) }\end{array}$ \\
\hline $350-400$ & $448-868$ & - & 0.800 & 0.64 & $0.052-0.057$ & $17.5-19$ \\
\hline
\end{tabular}



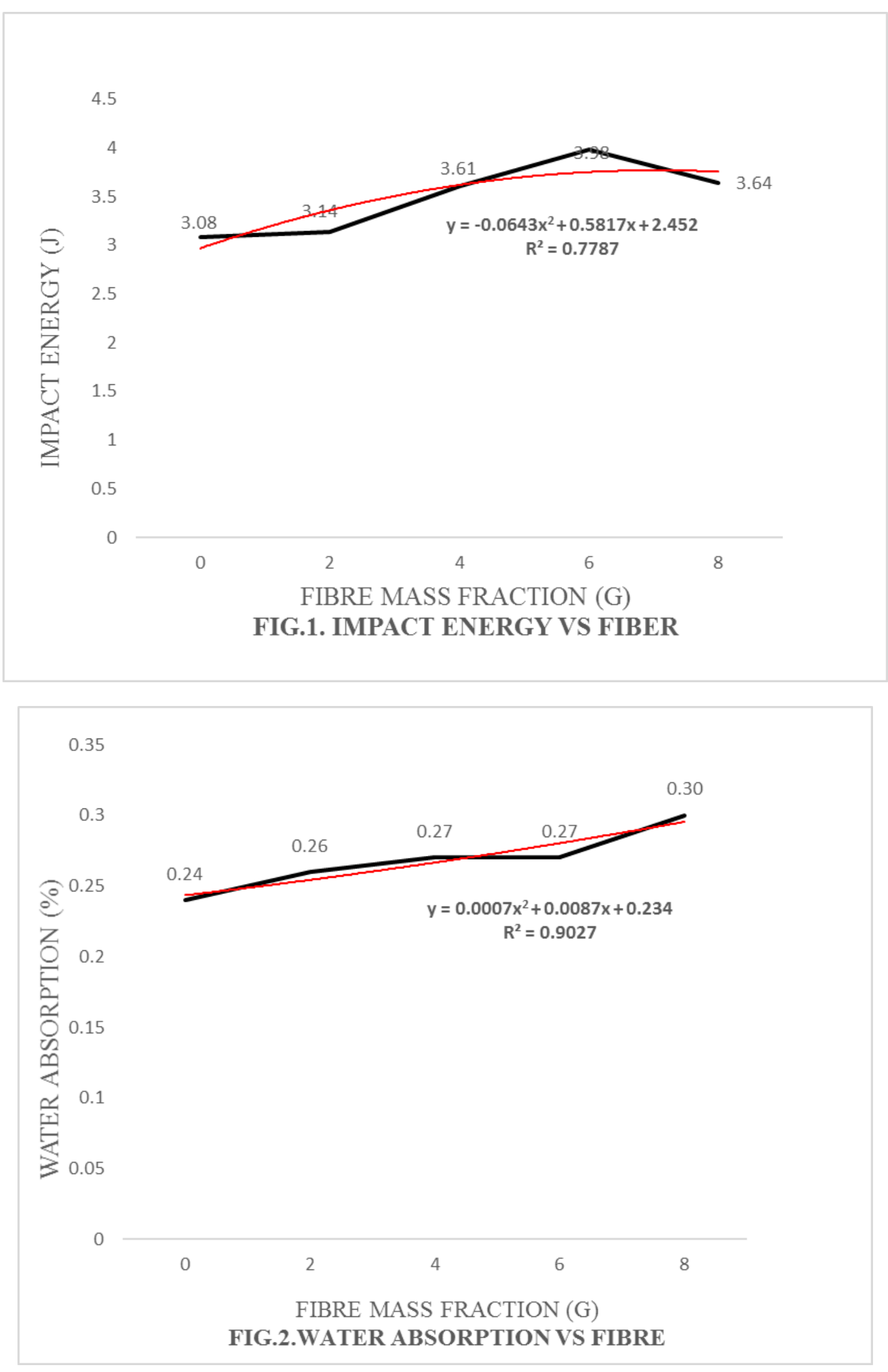

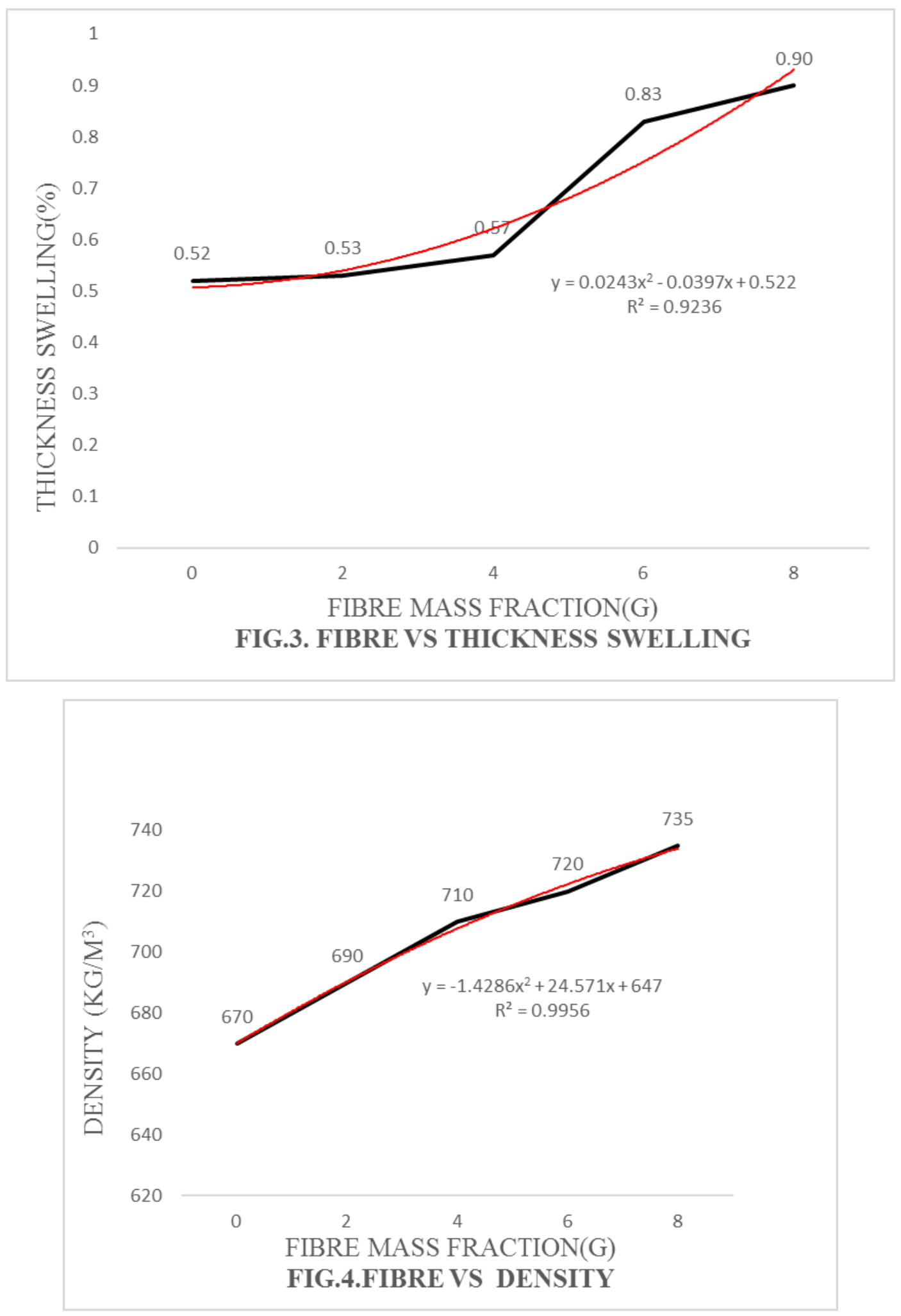

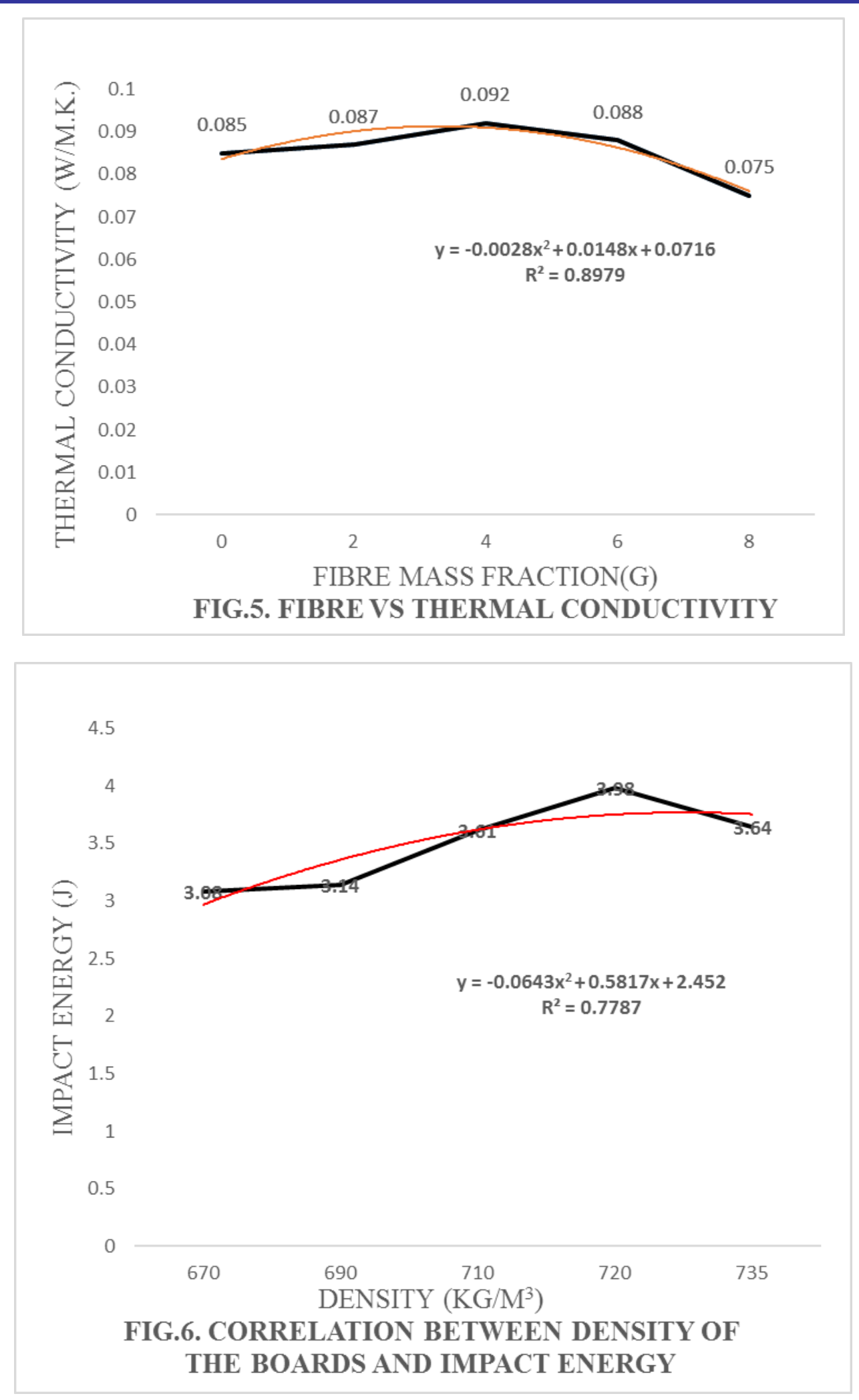

\section{DISCUSSION}

Thickness swelling and Water absorption values range between $0.52 \%-0.90 \%$ and $0.24 \%-0.30 \%$ respectively. The highest values of water absorption, $0.90 \%$ and thickness swelling, $0.30 \%$, were obtained at maximum cissus fibre reinforcement of $8 \%$. This implies that, increasing the fibre percentage in the board will increase the board affinity for water absorption. This increased rate for water absorption and Thickness swelling may have occurred due to hygroscopic nature of lignocelluloses fibres which allow for moisture intake. The trend obtained in this result correlate with Olawale, (2009)

Density of the boards is a function of fibre - cement ratio, it ranged between $670 \mathrm{~kg} / \mathrm{m}^{3}$ and $735 \mathrm{~kg} / \mathrm{m}^{3}$. The density increases with increased cissus fibre. The pulp fibre in the matrix which serve as both reinforcement and filler material control the density 
of the boards within acceptable range of $500 \mathrm{~kg} / \mathrm{m}^{3}-800 \mathrm{~kg} / \mathrm{m}^{3}$ for medium density fibre board. The polynomial rank correlation, $\mathrm{R}^{2}=0.78$ between density and impact energy of the boards as depicted in Fig 6 indicate that the impact energy of the board is also a function of density of the boards.

The impact energy obtained from the free fall method is the energy required to cause the failure of the board when subjected to impact loading. It can also be interpreted as the maximum impact loading beyond which failure will occur. The values ranged between $3.08 \mathrm{~J}$ and $3.98 \mathrm{~J}$, it is maximum at $8 \%$ cissus fibre reinforcement. The energy increased between $0 \%$ and $6 \%$ and reduces between $6 \%$ and $8 \%$ fibre reinforcement. This trend showed that, increasing the reinforcement of the composite above $8 \%$ fibre reduces the impact energy of the board and will therefore affect its ability to withstand more impact loading, this behaviour can also be traceable to excess fibre to cement ratio of the composite board. The same findings was reported on natural sponge fibre - reinforced cement boards by Olawale, 2009. Comparing the values obtained to the findings of Ekpunobi et al 2015 on the mechanical properties of waste paper ceiling board, it was observed that, the use of cissus fibre as additional reinforcement material is a factor that increase the impact energy values of the boards.

The thermal conductivity of the composite board determined heat conductivity potential of the board with respect to time and change in temperature when use as ceiling or wall siding material for construction. It ranged between $0.075 \mathrm{~W} / \mathrm{m} . \mathrm{K}$ and $0.092 \mathrm{~W} / \mathrm{m} . \mathrm{K}$. The maximum thermal conductivity of $0.092 \mathrm{~W} / \mathrm{m}$.K was obtained at cissus fibre reinforcement of $4 \%$ while the least $0.075 \mathrm{~W} / \mathrm{m} . \mathrm{K}$ was obtained $8 \%$. It was observed that increasing cissus fibre above $4 \%$ reduces the thermal conductivity of the boards, which is attributed to high interlock bonding spaces between the cissus fibre and cement. The thermal behaviour of this board correlate with the result of the thermal conductivity of the board produced from rice husk and waste paper by Ataguba, 2016.

\section{CONCLUSIONS AND RECOMMENDATION}

The results obtained from the study showed that, using cissus fibre as reinforcement materials for production of medium density board for ceiling and walling applications. This will eliminate energy consumption and environmental hazard caused by synthetic fibres The range values of the board impact energy, thermal conductivity, water absorption and thickness swelling fall within the standard values that will make the boards acceptable for use as light load bearing member for construction, the use of cissus fibre alone or in combination with other lignocelluloses fibre as reinforcement material and extension to production of fibre based composites for other applications such as roofing and flooring is hereby recommended.

\section{REFERENCE}

[1] Agopyan et al (2005).Developments on vegetable fibre-cement based materials in Sao Paulo, Brazil: An overview. Cement Concrete Composite. 27(5):527-536.

[2] Al-Qureshi H.A. (1999). The Use of Banana Fibre Reinforced Composites the Development of a Truck Body, Second International Wood and Natural Fibre Composites Symposium Kassel/Germany, pp.1-8

[3] Alakali,J.S, Irtwannge, S.V.and Mkavga, M.(2009) Rheological Characteristics of Food Gum on the Mechanical and Release Properties of Paracetamol Tablets- A factorial Analysis Journal of Basic and Applied Pharmaceutical Sciences; 31(2):131-136

[4] ASTM D7433-13 Standard Test Method for Measuring Surface Water Absorption of overlaid

[5] Wood based Panels. 2013 ASTM International West Conshocken P.A.

[6] ASTM C367/C367-09 Standard Test Method for strength properties of prefabricated architectural acoustical tile on lay in ceiling panels. 2014 ASTM International West Conshocken P.A.

[7] Benjamin C.T (1990). Fabrication and Performance of Natural Fiber-Reinforced Composite Materials 35th. International SAMPE Symposium, pp.970978 .

[8] Bentur A.and Mindess,S (1990) Fiber Reinforced Cementitious Composites Elsevier Science Publisher Limited, Essex, England.449 pp.

[9] U.E. Ekpunobi, E.C. Ohaekenyem, A.S. Ogbuagu, and E.N. Orjiako, "The mechanical properties of ceiling boards produced from waste paper". British Journal of Applied Science and Technology 2015 Vol 5(2) pp 166-172

[10] Lucas E.B. and Dahunsi, B.I.O. 2004. Characterisic of Three Western Nigerian Rattan Species in Relation Rattan Species in Relation to Their Utilization Construction Materials. Journal of Bamboo Rattan. 3(1); 45-46

[11] Mohr et al (2003a). Durability of pulp fiber-cement composites to wet/dry cycling Journal of Cement and Concrete Composites, 23pp 389-397.

[12] Moslemi, A. A. Souza M and Geimer, R. 2000. Accelerated Ageing of Cement Bonded Particles Board. In Proceedings of Fibre Particles Board Bonded with Inorganic Binders. Forest Products Research Society.

[13] Nielsen, L., Stang, H. and Poulsen P. L. (2007).Micro-Mechanical Analysis of Fibre Reinforced -Cementitious Composites. Journal of Advanced Concrete Technology. 5 (3), 373-382

[14] Oladele et al (2009) Development of Fibre Reinforced Cementitious Composite for Ceiling Application. Journal of Minerals and Materials Characterization and Engineering.Vol 8, No 8, pp583-590 